Article

\title{
General trends in Horiuti-Polanyi mechanism vs non-Horiuti-Polanyi mechanism for water formation on transition metal surfaces
}

\author{
Xitong Sun a, Jianfu Chen ${ }^{\mathrm{a}, \#, \text { P. Hu }}{ }^{\mathrm{a}, \mathrm{b}, *}$ \\ a Key Laboratory for Advanced Materials, Centre for Computational Chemistry and Research Institute of Industrial Catalysis, School of Chemistry and \\ Molecular Engineering, East China University of Science and Technology, Shanghai 200237, China \\ ${ }^{\mathrm{b}}$ School of Chemistry and Chemical Engineering, Queen's University Belfast, Belfast BT9 5AG, UK
}

\section{A R T I C L E I N F O}

\section{Article history:}

Received 9 June 2019

Accepted 20 June 2019

Published 5 February 2020

Keywords:

Hydrogenation

Horiuti-Polanyi mechanism

Water formation

Transition metal

Density functional theory

\begin{abstract}
A B S T R A C T
It is generally acknowledged in heterogeneous catalysis that hydrogenation follows the so-called Horiuti-Polanyi (HP) mechanism. In this work, a thorough investigation of the mechanism of hydrogenation of hydroxyl groups and 0 catalyzed by a series of transition metals was carried out through density functional theory calculations, as surface hydroxyls and 0 are very common species in many catalytic systems. It is found that different metal catalysts exhibit different mechanisms. On some metal catalysts, the non-HP mechanism is preferred, whereas the classic HP mechanism is favored on other catalysts. Detailed analyses of the metal-dependent mechanism shows that the activity toward the dissociation of $\mathrm{H}_{2}$ decides which mechanism is preferred. On active catalysts, such as $\mathrm{Ni}$ and $\mathrm{Pt}, \mathrm{H}_{2}$ prefers to dissociate with strong $\mathrm{H}$ adsorption energies, which lead to the classic HP mechanism being favored. On inactive surfaces, on the other hand, the adsorption of $\mathrm{H}$ is weak, which results in the non-HP mechanism being preferred. The parameter $\eta$, which is a structural descriptor, was defined to understand the different mechanisms.
\end{abstract}

(C) 2020, Dalian Institute of Chemical Physics, Chinese Academy of Sciences. Published by Elsevier B.V. All rights reserved.

\section{Introduction}

The hydroxyl group $(\mathrm{OH})$ is perhaps one of the most common species in heterogeneous catalysis as it can play an important role as both a reductant and an oxidant. There are many types of industrial reactions involving the $\mathrm{OH}$ group, such as Fischer-Tropsch synthesis [1-3], methane reformation [4,5], ammonia oxidation [6], as well as the ethanol synthesis reaction [7]. In the process of carbon dioxide hydrogenation, a moderate amount of $\mathrm{OH}$ groups and some adsorbed $\mathrm{O}^{*}$ are generated when water is used [8-11] that may cover the $\mathrm{Cu}$ surface, which block the active sites and affect the reaction rate to some extent. Traditionally, the hydroxyl groups and adsorbed 0 are removed from catalyst surfaces by reduction with $\mathrm{H}$ adsorbed on the surfaces both experimentally and theoretically, which results in the formation of water via the so-called classic Horiuti-Polanyi (HP) mechanism [12-14]. This involves a three-step process, namely, $\mathrm{H}_{2}$ adsorption, followed by dissociation, and hydrogenation by $\mathrm{H}$. In the reduction reaction, $\mathrm{H}_{2}$ is generally over a large quantity to increase the turn over frequency, and theoretical simulations are desirable for understanding the nature of the catalytic process.

Hydrogenation by adsorbed $\mathrm{H}$, which is the HP mechanism, was generally acknowledged, and other possibilities were vir-

\footnotetext{
* Corresponding author. Tel/Fax: +86-21-64253755; E-mail: p.hu@qub.ac.uk

\# Corresponding author. Tel/Fax: +86-21-64253755; E-mail: jfchen@ecust.edu.cn

This work was supported by the National Natural Science Foundation of China (21673072, 21333003, and 91845111)

DOI: S1872-2067(19)63434-0 | http://www.sciencedirect.com/science/journal/18722067 | Chin. J. Catal., Vol. 41, No. 2, February 2020
} 
tually neglected, until two interesting results were reported. The first result was that the non-Horiuti-Polanyi (non-HP) mechanism is favorable for the hydrogenation of acrolein when the catalyst used is $\mathrm{Ag}$ or $\mathrm{Au}$, as revealed through our previous theoretical work [15], and the other one was that the reductant reacts with $\mathrm{H}$ through a $\mathrm{H}_{2}$ molecule over supported Ag nanoparticles [16]. As for the catalyst, transition metals are widely used for hydrogenation reactions [17-20], especially, late transition metals are utilized for the oxycarbide redox reaction.

In addition to the two metals mentioned above, $\mathrm{Cu}$ is the active component in methanol synthesis [21,22], and Ni-based catalysts are used in the steam reforming of natural gas [23-25] $\left(\mathrm{C}_{x} \mathrm{H}_{y}+x \mathrm{H}_{2} \mathrm{O} \rightarrow x \mathrm{CO}_{2}+(x+y / 2) \mathrm{H}_{2}\right)$ and in methanation $[26,27]\left(\mathrm{CO}+3 \mathrm{H}_{2} \rightarrow \mathrm{CH}_{4}+\mathrm{H}_{2} \mathrm{O}\right)$; Pt metal is often utilized as a catalyst in water-gas shift reactions [28], in which the coupling of $\mathrm{OH}^{*}$ with $\mathrm{H}^{*}$ is generally accepted [29]. It is well known that transition metals with different activities are widely used to catalyze hydrogenation reactions [17-19,30], but the hydrogenation mechanism may be sensitive to the surface type [15]. The following important questions remain to be answered. Are all the adsorbed $\mathrm{OH}^{*}$ or $\mathrm{O}^{*}$ hydrogenated via the HP mechanism? Are there any possibilities that $\mathrm{OH}^{*}$ or $\mathrm{O}^{*}$ are attacked by molecular $\mathrm{H}_{2}$ ? If the answer is yes, when is the non-HP mechanism favored? To obtain a good understanding, systematic exploration of the reaction mechanism was carried out for representative transition metals, such as $\mathrm{Ni}, \mathrm{Pt}, \mathrm{Cu}, \mathrm{Ag}$, and $\mathrm{Au}$, based on density functional theory (DFT) calculations in this work. Two surfaces with different Miller indices were investigated, including the stepped (211) surfaces and the flat (111) surfaces.

In this work, the adsorption and dissociation of $\mathrm{H}_{2}$ were first studied. All the hydrogenation pathways were investigated and detailed comparisons are made. A structural descriptor has been introduced to analyze the structures based on the reaction mechanisms.

\section{Model and method}

First-principles energy calculations were performed within the density functional theoretical $[31,32]$ framework by using Vienna $a b$ initio simulation package [33-35]; Perdew-Burke-Ernzerhof functional with generalized gradient approximation [36] was employed to describe the exchange correlation between electrons [37]. PAW method [38,39] was used to describe the core-electron interactions, and the cut-off energy of the plane-wave basis set was set as $400 \mathrm{eV}$. For Ni, the calculations were carried out with spin-polarized. The geometry was relaxed using Broyden method, which stopped only when the force of the ions became less than $0.05 \mathrm{eV} / \AA$. The lattice constants of the unit cells were optimized first and then periodic four-layer slabs were modeled as metal surfaces. The vacuum region between the slabs was in excess of $15 \AA .4 \times$ $4 \times 1$ k-point sampling of Monkhorst Pack scheme was used for the $p(1 \times 4)$ supercell of $f c c(211)$ and the $p(3 \times 3)$ supercell of fcc(111) surfaces. The bottom two layers of the slab were fixed at the bulk truncated position, with the top two layers fully relaxed during the structural optimization. All the adsorption geometries were optimized using a force-based conjugate gradient algorithm, while the transition states (TSs) of reactions were searched using a constrained minimization scheme [40-42]. The adsorption energy of surface-absorbed species $X$ was defined as follows:

$$
E_{\text {ads }}(X)=E_{X}+\text { surface }-\left(E_{\text {surface }}+E_{X}\right)
$$

where $E_{X}+$ surface, $E_{\text {surface, }}$ and $E_{X}$ are the optimized energies of the total adsorption system, the adsorbate in the gas phase, and the clean surface, respectively. A more negative value of $E_{\text {ads }}$ suggests stronger binding on the surface.

\section{Results and discussion}

A series of metal surfaces was investigated for $\mathrm{OH} / \mathrm{O}$ hydrogenation, including $\mathrm{Ni}, \mathrm{Pt}, \mathrm{Cu}, \mathrm{Au}$, and $\mathrm{Ag}$. The mechanistic study of water formation from $\mathrm{OH}$ hydrogenation, as well as that of $0^{*}$ hydrogenation, was extended from the flat (111) surfaces to the stepped (211) surfaces.

\section{1. $\mathrm{H}_{2}$ dissociation}

First, we examined the adsorption and dissociation of $\mathrm{H}_{2}$ on the abovementioned metal surfaces. Fig. 1(c) shows that in the TS, two adsorbed H atoms occupy the fcc and top sites on the (111) surface, whereas they are located at the bridge and top sites along the stepped edge of the (211) surface, respectively. The corresponding energy values are listed in Table 1. Accordingly, the relationships between the dissociative energy barrier and the adsorption energy as well as the reaction energy could be mapped out, as illustrated in Fig. 1(a,b). The adsorption of $\mathrm{H}_{2}$ on $\mathrm{Cu}, \mathrm{Ag}$, and $\mathrm{Au}$ surfaces is very weak, whereas a strong bonding is observed between $\mathrm{H}_{2}$ and the catalytically active $\mathrm{Ni}$ surface. Particularly, at the stepped edge sites of Ni(211), the adsorption energy of $\mathrm{H}_{2}\left(E_{\mathrm{ads}}\left(\mathrm{H}_{2}^{*}\right)\right)$ could reach $-0.48 \mathrm{eV}$.

Pt catalysts find wide applications in redox reactions leading to water formation [43-46], as the dissociative adsorption of $\mathrm{H}_{2}$ on $\mathrm{Pt}$ is very facile. It is found that the adsorption of $\mathrm{H}_{2}$ on both $\mathrm{Pt}(211)$ and $\mathrm{Pt}(111)$ is very weak, but that the dissociative adsorption is reasonably strong $[47,48]$. The barriers for $\mathrm{H}_{2}$ dissociation $E_{\mathrm{a}}\left(\mathrm{H}_{2, \mathrm{dis}}{ }^{*}\right)$ on $\mathrm{Ni}$ and Pt surfaces are very low (less than $0.2 \mathrm{eV}$ ), and the $\mathrm{H}-\mathrm{H}$ bond can be easily broken. The strong driving force for $\mathrm{H}_{2}$ dissociation renders the reaction strongly exothermic. Their energies are reduced by 0.65 and $0.87 \mathrm{eV}$ over $\mathrm{Ni}(211)$ and $\mathrm{Ni}(111)$ surfaces and by 1.22 and $1.00 \mathrm{eV}$ over Pt(211) and Pt(111) surfaces, respectively. The calculated results are in good agreement with those of Zhu et al. [46] on the reforming of methane on Ni(111).

$\mathrm{Au}$ and $\mathrm{Ag}$ surfaces display low activities toward $\mathrm{H}_{2}$ adsorption and the barriers for $\mathrm{H}_{2}$ dissociation are very high. The $E_{\mathrm{a}}$ $\left(\mathrm{H}_{2, \mathrm{dis}}{ }^{*}\right)$ values exceed $1 \mathrm{eV}$ on $\mathrm{Ag}(111)$, $\mathrm{Au}$ (111), and $\mathrm{Ag}(211)$. On the other hand, $E_{\mathrm{a}}\left(\mathrm{H}_{2, \mathrm{dis}}{ }^{*}\right)$ is $0.57 \mathrm{eV}$ on $\mathrm{Au}(211)$ surface, which indicates that the activities of $\mathrm{Au}$ are distinct over different crystal surfaces. The $\mathrm{H}_{2}$ dissociation reaction is endothermic on Au and Ag surfaces, which suggests that the forward reaction is unfavorable. On the two $\mathrm{Cu}$ surfaces, although the dissociative chemisorption energy $\Delta E\left(\mathrm{H}_{2, \mathrm{dis}}{ }^{*}\right)$ is $\sim-0.5 \mathrm{eV}$, the dissociation barrier $E_{\mathrm{a}}\left(\mathrm{H}_{2, \text { dis }}{ }^{*}\right)$ requires an energy of $\sim 0.5 \mathrm{eV}$. 


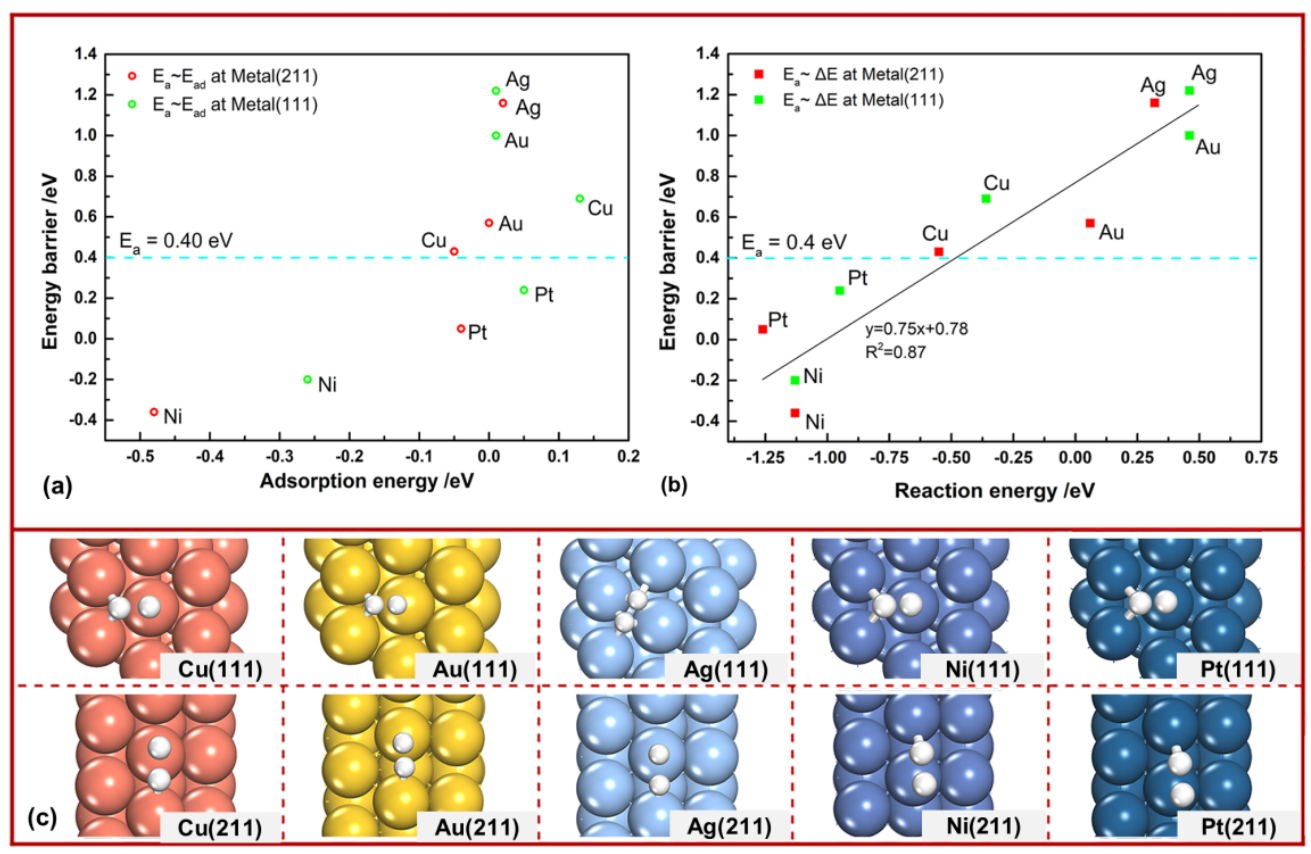

Fig. 1. (a) Correlations between $\mathrm{H}_{2}$ activation energy and adsorption energy on metal (211) and (111) surfaces; (b) correlations between $\mathrm{H}_{2}$ activation energy and the energy of $\mathrm{H}_{2}$ dissociation on metal (211) and (111) surfaces; (c) TS structures associated with $\mathrm{H}_{2}$ dissociation. The red circles and square points represent the data of the (211) surfaces, whereas the green ones pertain to the (111) surfaces.

Subsequently, we studied the relations of $E_{\text {a }}$ with $E_{\text {ads }}$ and $\Delta E$. Some correlations were identified, as shown in Fig. 1(a, b). It is found that there is no linear relationship between $E_{\mathrm{a}}$ and $E_{\text {ads, }}$ but the data points are located at two different regions: the data points of inactive metals, which exhibit higher dissociation barriers and lower adsorption energies, can be found in the upper right corner, whereas those of active metals are observed in the bottom left area (Fig. 1(a)).

On the other hand, a linear correlation between $E_{\mathrm{a}}$ and $\Delta E$ can be observed, as revealed in Fig. 1(b). These results demonstrate that $\mathrm{H}_{2}$ dissociation on these metals is strongly related to the adsorption of $\mathrm{H}^{*}$. It is clear that the data in the bottom left region represent the catalytically active metals for $\mathrm{H}_{2}$ dissociation, whereas those at the upper right corner correspond to the catalytically inert metals for $\mathrm{H}_{2}$ dissociation, though they may be possible catalysts for $\mathrm{H}_{2}$ to hydrogenate $\mathrm{OH}^{*} / \mathrm{O}^{*}$. The bondings of $\mathrm{H}^{*}$ with $\mathrm{Pt}$ and $\mathrm{Ni}$ surface atoms lower the energies $\mathrm{Ev}$ by $0.3-0.6 \mathrm{eV}$. Moreover, the $\mathrm{H}_{2}$ dissociation barriers are no

Table 1

Adsorption energies $\left(E_{\text {ads }}\right)$ of $\mathrm{H}_{2}$, energy barriers $\left(E_{\mathrm{a}}\right)$, and enthalpy changes $(\Delta E)$ for $\mathrm{H}_{2}$ dissociation and the distance between two $\mathrm{H}$ atoms in the TSs $\left(D_{\text {dis }}\right)$.

\begin{tabular}{lcrcrc}
\hline & Metal & $E_{\text {ads }} / \mathrm{eV}$ & $E_{\mathrm{a}} / \mathrm{eV}$ & $\Delta E / \mathrm{eV}$ & $D_{\text {dis }} / \AA$ \\
\hline (211) facet & $\mathrm{Cu}$ & -0.05 & 0.48 & -0.50 & 1.39 \\
& $\mathrm{Au}$ & 0.00 & 0.57 & 0.06 & 1.35 \\
& $\mathrm{Ag}$ & 0.02 & 1.14 & 0.34 & 1.55 \\
& $\mathrm{Ni}$ & -0.48 & 0.12 & -0.65 & 1.28 \\
& $\mathrm{Pt}$ & -0.04 & 0.10 & -1.22 & 1.30 \\
$(111)$ facet & $\mathrm{Cu}$ & 0.13 & 0.56 & -0.49 & 1.38 \\
& $\mathrm{Au}$ & 0.01 & 1.00 & 0.45 & 1.33 \\
& $\mathrm{Ag}$ & 0.01 & 1.21 & 0.45 & 1.27 \\
& $\mathrm{Ni}$ & -0.26 & 0.06 & -0.87 & 1.13 \\
& $\mathrm{Pt}$ & 0.05 & 0.19 & -1.00 & 1.15 \\
\hline
\end{tabular}

more than $0.3 \mathrm{eV}$. These results are consistent with those of Phatak et al. [49]. On $\mathrm{Ag}(111), \mathrm{Au}(111)$, and $\mathrm{Ag}(211), E_{\text {a }}$ are rather high, and the formed $\mathrm{H}^{*}$ is also not stable on these surfaces. The $\mathrm{H}_{2}$ dissociation may not proceed. Hence, the reaction equilibrium shifts to $\mathrm{H}_{2}$ in the gas phase, which results in the attack of $\mathrm{OH}^{*} / \mathrm{O}^{*}$ by $\mathrm{H}_{2}$ becoming more probable. The $\mathrm{H}_{2}$ dissociation performance on $\mathrm{Cu}$ surfaces is in the middle of the corresponding performances on the metal surfaces. Therefore, it is not easy to energetically assess whether $\mathrm{H}_{2}$ can be activated. This will be further discussed in section 3.2.

\subsection{Comparison of hydrogenation mechanisms}

Both the classic HP hydrogenation and the non-HP hydrogenation mechanisms of $\mathrm{OH}^{*} / \mathrm{O}^{*}$ reduction on metal surfaces were investigated. The energy profiles over three typical surfaces, which include inactive $\operatorname{Ag}(211)$, active $\operatorname{Pt}(211)$, and the moderately active $\mathrm{Cu}(211)$, are shown in Fig. 2.

\subsubsection{Mechanisms of $\mathrm{OH}^{*}$ removal}

As illustrated by the solid line in Fig. 2, the two mechanisms of $\mathrm{OH}^{*}$ hydrogenation were compared. $\mathrm{H}_{2}$ dissociation was also considered, which is essential to understand the hydrogenation by $\mathrm{H}_{2}$. It can be seen from Fig. 2(a) that, on $\mathrm{Pt}(211)$, the $\mathrm{H}_{2}$ dissociation is easier to occur than coupling with $\mathrm{OH}^{*}$ species, although the latter displays a lower energy barrier than the direct hydrogenation of $\mathrm{OH}^{*}$ by atomic $\mathrm{H}^{*}(0.25 \mathrm{eV}$ vs. $0.90 \mathrm{eV})$; the data are listed in Table 2 . This result suggests that the classic HP mechanism is more favorable than non-HP mechanism on active surfaces. Similar reaction characteristics are found on the Pt(111), Ni(211), as well as Ni(111), surfaces. Fig. 2(b) elucidates the difference between the two hydrogenation mecha- 


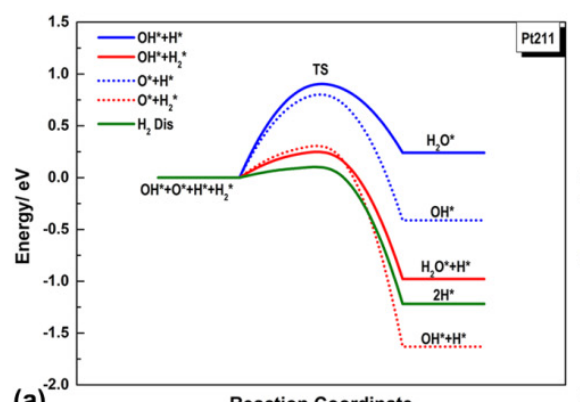

(a)

(a) Reaction Coordinate

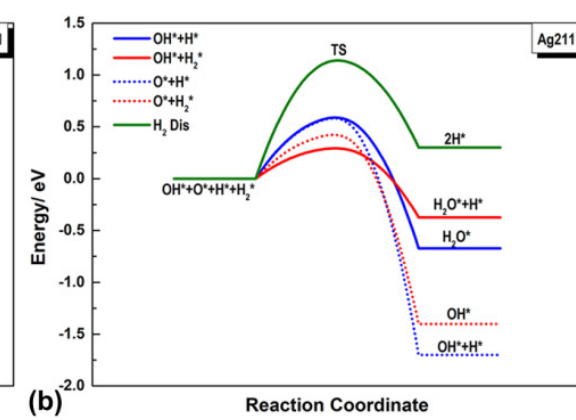

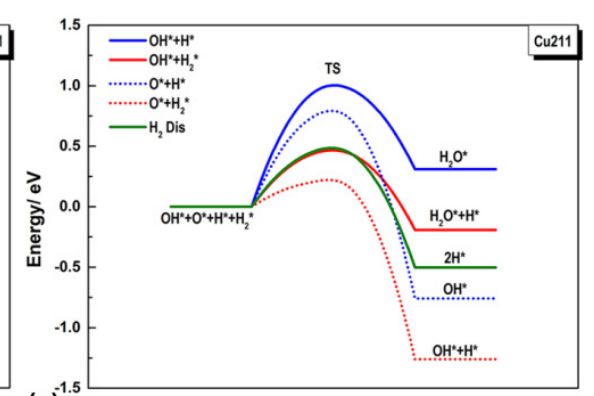

(c) $)^{-1}$

genation mechanism (solid line) and $\mathrm{H}_{2}$ dissociation on representative surfaces: (a) $\mathrm{Pt}(211)$; (b) $\mathrm{Ag}(211)$; (c) $\mathrm{Cu}(211)$.

nisms on $\mathrm{Ag}(211)$, which is a representative inactive metal. $\mathrm{H}_{2}$ dissociation exhibits the highest barrier (1.14 eV; Table 1), and the barrier for direct $\mathrm{OH}^{*}$ hydrogenation by $\mathrm{H}^{*}$ is $0.6 \mathrm{eV}$; the hydrogenation of $\mathrm{OH}^{*}$ by $\mathrm{H}_{2}$ reveals a barrier that is as low as $0.3 \mathrm{eV}$. Hence, the reduction of $\mathrm{OH}^{*}$ by $\mathrm{H}_{2}$ catalyzed by inactive metals offers an advantage over the mechanism of direct addition of atomic $\mathrm{H}^{*}$. The other inactive surfaces, such as $\mathrm{Ag}(111)$, $\mathrm{Au}(211), \mathrm{Au}(111)$, and $\mathrm{Cu}(111)$, also exhibit this tendency, as observed in Table 2.

The difference in mechanism between $\mathrm{OH}^{*}$ hydrogenation on active metals $(\mathrm{Pt}, \mathrm{Ni})$ and that on inactive metals $(\mathrm{Ag}, \mathrm{Au})$ is obvious. However, $\mathrm{Cu}(211)$ is a special case: it displays a moderate activity, which results in a dependence of the mechanism on the specific reaction condition. The $\mathrm{H}_{2}$ dissociation and the hydrogenations by atomic and molecular hydrogens on $\mathrm{Cu}(211)$ are compared in Fig. 2(c). The hydrogenation of $\mathrm{OH}^{*}$ by $\mathrm{H}_{2}{ }^{*}$ reveals a barrier that is comparable to that of $\mathrm{H}_{2}$ dissociation $(0.47 \mathrm{eV}$ vs. $0.48 \mathrm{eV})$. Although the hydrogenation of $\mathrm{OH}^{*}$ by $\mathrm{H}^{*}$ exhibits a higher barrier than that by $\mathrm{H}_{2}$, the adsorption of $\mathrm{H}^{*}$ on $\mathrm{Cu}(211)$ is stronger than that of $\mathrm{H}_{2}{ }^{*}$. As a result, the balance between the adsorption energy of $\mathrm{H}^{*}$ and the $\mathrm{H}_{2}$ dissociation barrier would determine which pathway is favored, and can be affected by the experimental reaction temperature and the partial pressure. Our results show that the non-HP mechanism dominates at low temperatures, whereas the classic HP mechanism is more favored when the temperature is significantly increased.

\subsubsection{Mechanisms of $O^{*}$ hydrogenation}

Considering the importance of adsorbed $\mathrm{O}^{*}$ in heterogene- ous catalysis, the hydrogenation of $0^{*}$ via the two different pathways was researched and the results on three representative surfaces are shown in the form of dotted lines in Fig. 2. On $\mathrm{Pt}$ (211) surface, $\mathrm{H}_{2}$ dissociation is easier to occur than coupling with $\mathrm{O}^{*}$ species, although the latter displays a much lower energy barrier than that for direct hydrogenation of $\mathrm{O}^{*}$ by atomic $\mathrm{H}^{*}(0.30 \mathrm{eV}$ vs. $0.80 \mathrm{eV})$. Therefore, the classic HP mechanism is preferred. Similar results are obtained on the other three active surfaces, namely, $\operatorname{Pt}(111), \mathrm{Ni}(211)$, and $\mathrm{Ni}(111)$.

On $\mathrm{Ag}(211)$, the hydrogenation of $\mathrm{O}^{*}$ by $\mathrm{H}_{2}{ }^{*}$ reveals the lowest barrier $(0.42 \mathrm{eV})$, in comparison with 0.58 and $1.14 \mathrm{eV}$ for hydrogenation by atomic $\mathrm{H}^{*}$ and $\mathrm{H}_{2}$ dissociation, respectively. On $\mathrm{Ag}(111), \mathrm{Au}(211), \mathrm{Au}(111), \mathrm{Cu}(211)$, and $\mathrm{Cu}(111)$, the barriers for hydrogenation by $\mathrm{H}_{2}$ are found to be $0.38,0.17,0.51$, 0.22 , and $0.41 \mathrm{eV}$, respectively, whereas the $\mathrm{H}_{2}$ dissociation barriers are $1.21,0.57,1.00,0.48$, and $0.56 \mathrm{eV}$, respectively. The energy barrier for the non-HP hydrogenation mechanism is lower than that for the classic HP mechanism on every surface except $\mathrm{Au}(111)$. On $\mathrm{Au}(111)$, the two barriers are nearly equal and the $\mathrm{H}_{2}$ dissociative adsorption energy $\left(E_{\text {ads }}\left(\mathrm{H}^{*}\right)\right)$ is positive $(0.23 \mathrm{eV}) ; E_{\text {ads }}\left(\mathrm{H}_{2}{ }^{*}\right)$ almost equals zero. Therefore, the effective barrier for $\mathrm{O}^{*}$ hydrogenation by $\mathrm{H}^{*}$ is $0.73 \mathrm{eV}$, which is higher than that for $\mathrm{O}^{*}$ hydrogenation by $\mathrm{H}_{2}(0.51 \mathrm{eV})$. In other words, the $\mathrm{O}^{*}$ hydrogenation is similar to the $\mathrm{OH}^{*}$ hydrogenation.

\subsubsection{Trend of mechanism preference}

A descriptor, $E_{\text {ads }}\left(\mathrm{O}^{*}\right)$ was utilized to fit the energy barriers of both $\mathrm{OH}^{*}$ and $\mathrm{O}^{*}$ hydrogenations as well as those of $\mathrm{H}_{2}$ dissociation on these surfaces, considering that the adsorption energy of $\mathrm{O}^{*}$ may be of importance. The value of $E_{\text {ads }}\left(\mathrm{O}^{*}\right)$ may be a

Table 2

Calculated energy barriers and the energy changes in $\mathrm{OH}^{*}$ and $\mathrm{O}^{*}$ hydrogenation reactions. The energy unit is eV.

\begin{tabular}{|c|c|c|c|c|c|c|c|c|}
\hline \multirow{2}{*}{ Step } & \multicolumn{2}{|c|}{$\mathrm{OH}^{*}+\mathrm{H}^{*}$} & \multicolumn{2}{|c|}{$\mathrm{OH}^{*}+\mathrm{H}_{2}{ }^{*}$} & \multicolumn{2}{|c|}{$\mathrm{O}^{*}+\mathrm{H}^{*}$} & \multicolumn{2}{|c|}{$\mathrm{O}^{*}+\mathrm{H}_{2}{ }^{*}$} \\
\hline & $E_{\mathrm{a}}$ & $\Delta E$ & $E_{\mathrm{a}}$ & $\Delta E$ & $E_{\mathrm{a}}$ & $\Delta E$ & $E_{\mathrm{a}}$ & $\Delta E$ \\
\hline $\mathrm{Cu}(211)$ & 1.00 & 0.31 & 0.47 & -0.19 & 0.79 & -0.76 & 0.22 & -1.26 \\
\hline $\mathrm{Au}(211)$ & 0.65 & -0.89 & 0.45 & -0.83 & 0.34 & -1.77 & 0.17 & -1.71 \\
\hline $\operatorname{Ag}(211)$ & 0.59 & -0.67 & 0.29 & -0.37 & 0.58 & -1.70 & 0.42 & -1.40 \\
\hline $\mathrm{Ni}(211)$ & 1.17 & 0.67 & 0.93 & 0.02 & 1.08 & 0.05 & 0.98 & -0.71 \\
\hline $\operatorname{Pt}(211)$ & 0.90 & 0.24 & 0.25 & -0.98 & 0.80 & -0.41 & 0.30 & -1.63 \\
\hline $\mathrm{Cu}(111)$ & 1.08 & -0.16 & 0.28 & -0.65 & 0.99 & -0.66 & 0.41 & -1.15 \\
\hline $\mathrm{Au}(111)$ & 0.50 & -1.51 & 0.22 & -1.05 & 0.50 & -1.52 & 0.51 & -1.07 \\
\hline $\operatorname{Ag}(111)$ & 0.72 & -0.97 & 0.33 & -0.52 & 0.97 & -1.75 & 0.38 & -1.30 \\
\hline $\mathrm{Ni}(111)$ & 1.40 & 0.41 & 0.59 & -0.46 & 1.25 & 0.27 & 0.82 & -0.60 \\
\hline $\mathrm{Pt}(111)$ & 0.59 & -0.67 & 0.05 & -1.24 & 1.02 & 0.01 & 0.41 & -0.99 \\
\hline
\end{tabular}



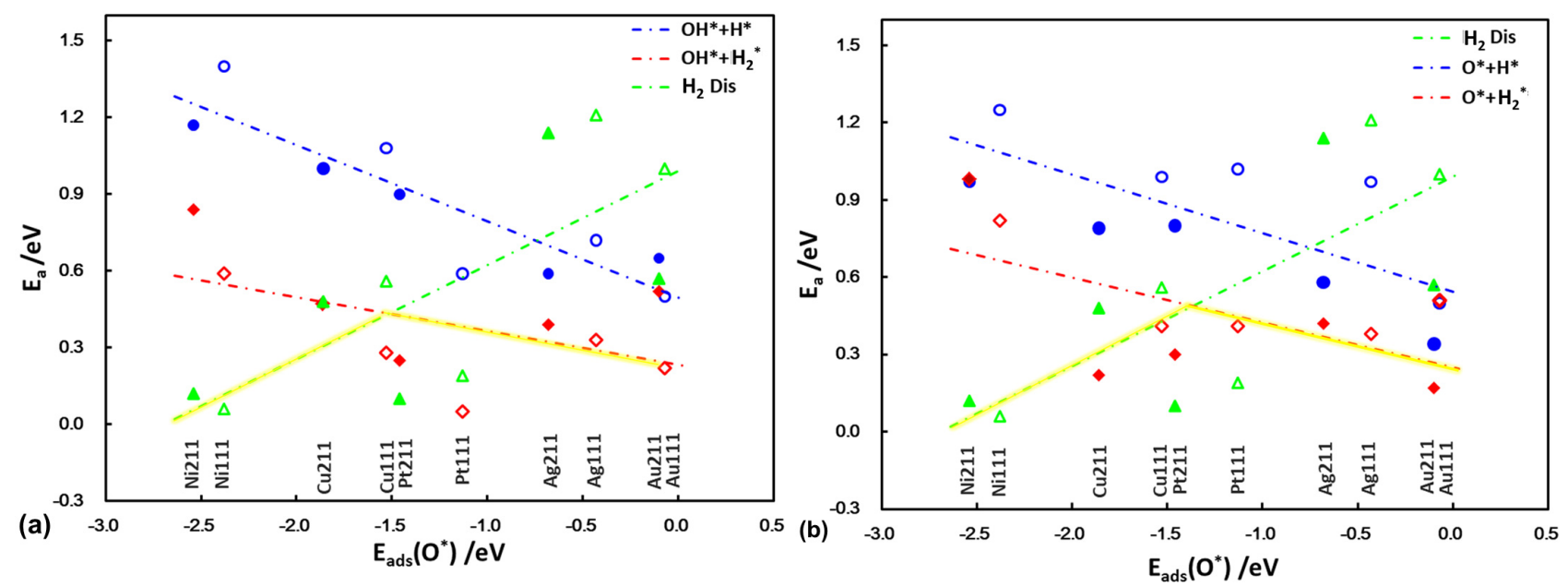

Fig. 3. Relations between the energy barrier and the $\mathrm{O}^{*}$ chemisorption energy $\left(E_{\mathrm{ads}}\left(\mathrm{O}^{*}\right)\right.$ ) for (a) $\mathrm{OH}^{*}$ hydrogenation and $(\mathrm{b}) \mathrm{O}^{*}$ hydrogenation on a series of surfaces, in conjunction with the results for $\mathrm{H}_{2}$ dissociation (the blue circles correspond to the classic HP hydrogenation mechanism, the red squares to hydrogenation by molecular hydrogen, and the green triangles to $\mathrm{H}_{2}$ dissociation). Each column corresponds to one catalytic surface, and the solid dots represent the data obtained from the stepped (211) surfaces, whereas the hollow dots correspond to the flat (111) surfaces.

key measure of catalytic activity. The results are displayed in Fig. 3.

We can observe the following features in the figure. First, $E_{\mathrm{a}}$ $\left(\mathrm{H}_{2, \text { dis }}{ }^{*}\right)$ changes linearly as a function of $E_{\text {ads }}\left(\mathrm{O}^{*}\right)$. The more negative the $E_{\text {ads }}\left(\mathrm{O}^{*}\right)$ value, the lower is the dissociation barrier, which indicates that there are some correlations between $0^{*}$ adsorption and $\mathrm{H}_{2}$ reactivity, as reported by Wang et al. [50-52]. Secondly $E_{\mathrm{a}}$, linearly increases with $E_{\mathrm{ads}}\left(\mathrm{O}^{*}\right)$ for both the hydrogenation pathways. The strong bonding between $\mathrm{OH}^{*}$ and the surface atoms inhibits the reactivity and enhances the hydrogenation barrier. Thirdly, the fact that nearly all the red square points (corresponding to the hydrogenation by $\mathrm{H}_{2}$ ) lie below the blue circles (which represent the HP mechanism) shows that the energy barriers of the non-HP mechanism are lower than those of the HP mechanism. However, the mechanism changes when the green line crosses the red line; the lines beyond the point of intersection are displayed in yellow in Fig. 3. Starting from the left hand side, the HP mechanism is preferred and, after the intersection point, the non-HP mechanism is favored. Of course, this is only a qualitative description of the trend.

It is obvious that the geometric effect should be of importance in determining which of the two mechanisms is preferred [53]. Fig. 4 shows the TS structures of $\mathrm{OH}^{*} / \mathrm{O}^{*}$ hydrogenation on both (211) and (111) surfaces. For the pathway of hydrogenation by $\mathrm{H}_{2}$, the TS structure of $\mathrm{HO}-\mathrm{HH} / \mathrm{O}-\mathrm{HH}$ is parallel to the surface, with a relatively flat configuration, which results in a better orbital overlap. On the contrary, for the pathway of hydrogenation by $\mathrm{H}$, the TS structure of $\mathrm{HO}-\mathrm{H} / \mathrm{O}-\mathrm{H}$ is inclined to the surface, especially at the step edge site on (211). This agrees well with reports that metal (211) surfaces exhibit higher activities for bond breaking than metallic (111) surfaces $[43,54,55]$.

\subsection{Structure of hydrogenation by $\mathrm{H}_{2}$}

It is worth pointing out that whether the mechanism of hydrogenation by $\mathrm{H}_{2}$ or the classic HP mechanism is favored depends on the nature of the TS structure, in particular, the distance between two $\mathrm{H}$ atoms is of importance. Our DFT calculations revealed the bond lengths between two $\mathrm{H}$ atoms in the TSs of hydrogenation by $\mathrm{H}_{2}$ on all the metal surfaces (Table 3).

To characterize the TS structures of non-HP hydrogenation, the distance between $\mathrm{H}$ atoms is inadequate. Therefore, a parameter $\eta$ was introduced, which is defined as follows:

$$
\eta=\frac{\left(D_{\mathrm{i}}-D_{\mathrm{H}_{2}}\right)}{\left(D_{\text {dis }}-D_{\mathrm{H}_{2}}\right)}
$$

where $D_{\mathrm{i}}$ is the distance between two $\mathrm{H}$ in the TS of molecular hydrogenation of $\mathrm{OH}^{*}$ or $\mathrm{O}^{*}$. $D_{\mathrm{H} 2}$ is the bond length of optimized $\mathrm{H}_{2}$, which is calculated to be $0.75 \AA$ in our work. $D_{\text {dis }}$ is the distance between two $\mathrm{H}$ in the TS of $\mathrm{H}_{2}$ dissociation.

The parameter $\eta$ is a measure of the $\mathrm{H}-\mathrm{H}$ separation in the TS of hydrogenation, and its value is $0<\eta<1$, by definition. The lower and upper boundaries represent the structure of the $\mathrm{H}_{2}$ molecule in the gas phase and the $\mathrm{H}_{2}$ dissociation structure in the TS, respectively. The higher the $\eta$ value, the more similar is the structure of $\mathrm{H}-\mathrm{H}$ in the $\mathrm{TS}$ of $\mathrm{OH}^{*}$ or $\mathrm{O}^{*}$ hydrogenation to that of $\mathrm{H}_{2}$ dissociation. Fig. 5 shows the $\eta$ values of all the steps of hydrogenation by $\mathrm{H}_{2}$ on both (211) and (111) surfaces as functions of the metal d-band centers [56,57]. The $\eta$ values for the $\mathrm{Pt}$ and $\mathrm{Ni}$ surfaces are not less than 0.4 , being 0.65 (Pt(211)), $0.57(\mathrm{Ni}(211))$ for $\mathrm{OH}^{*}$ hydrogenation and 0.53 (Pt(211)), 0.55 (Ni(211)) for $\mathrm{O}^{*}$ hydrogenation on the stepped surfaces vs. $0.64(\operatorname{Pt}(111)), 0.68(\mathrm{Ni}(111))$ and $0.49(\mathrm{Pt}(111))$, $0.63(\mathrm{Ni}(111))$ on the flat surfaces. On the other hand, the $\eta$ values of $\mathrm{Au}$ and $\mathrm{Ag}$ are less than 0.4, being $0.27(\mathrm{Au}(211))$, 0.25 (Ag(211)), $0.18(\mathrm{Au}(111)), 0.31(\mathrm{Ag}(111))$ and 0.16 (Au(211)), 0.12 (Ag(211)), 0.14 (Au(111)), 0.18 (Ag(111)), which correspond to the hydrogenation of $\mathrm{OH}^{*}$ and $\mathrm{O}^{*}$ by $\mathrm{H}_{2}$. Likewise, on $\mathrm{Cu}$ surfaces, the $\eta$ values are found to be 0.19 ( $\mathrm{Cu}(211)), 0.34(\mathrm{Cu}(111))$ and $0.23(\mathrm{Cu}(211)), 0.25(\mathrm{Cu}(111))$ for $\mathrm{OH}^{*}$ and $\mathrm{O}^{*}$ for the non-HP mechanism. 


\begin{tabular}{|c|c|c|c|c|}
\hline Surface & $\mathrm{OH}^{*}+\mathrm{H}^{*}$ & $\mathrm{OH}^{*}+\mathrm{H}_{2}{ }^{*}$ & $\mathrm{O}^{*}+\mathrm{H}^{*}$ & $\mathrm{O}^{*}+\mathrm{H}_{2}{ }^{*}$ \\
\hline $\mathrm{Ni}(111)$ & & & & \\
\hline $\operatorname{Pt}(111)$ & & & & \\
\hline $\mathrm{Cu}(111)$ & & & & \\
\hline $\mathrm{Au}(111)$ & & & & \\
\hline $\operatorname{Ag}(111)$ & & & & \\
\hline $\mathrm{Ni}(211)$ & & & & \\
\hline $\operatorname{Pt}(211)$ & & & & \\
\hline $\mathrm{Cu}(211)$ & & & & \\
\hline $\mathrm{Au}(211)$ & & & & \\
\hline $\operatorname{Ag}(211)$ & & & & \\
\hline
\end{tabular}

Fig. 4. TS structures of $\mathrm{OH}^{*}$ and $\mathrm{O}^{*}$ hydrogenation on (211) and (111) surfaces. Red: $\mathrm{O}$; white: $\mathrm{H}$; light blue: $\mathrm{Ni}$; dark blue: $\mathrm{Pt}$; orange: $\mathrm{Cu}$; gold: $\mathrm{Au}$; sky blue: Ag.

It is clear that $\mathrm{Ni}$ and $\mathrm{Pt}$ are active catalysts, whereas $\mathrm{Au}$ and $\mathrm{Ag}$ are inactive. Therefore, the upper boundary is approximately determined by the $\eta$ value of 0.49 for $\mathrm{Ni}$ and $\mathrm{Pt}$, and the lower one by the $\eta$ value of 0.31 for $\mathrm{Au}$ and $\mathrm{Ag}$, which are displayed as brown and yellow triangles, respectively, in Fig. 5. The center for this region is determined to be $\eta=0.41$ by calculating the geometric average of the $\eta$ values. The boundary zone divides the data into two regions. On the left hand side of Fig. 5, i.e., $\eta$ values below 0.41 , the $\mathrm{H}-\mathrm{H}$ distances in the TSs of
Table 3

Bond distances between two $\mathrm{H}$ atoms in the TSs of elementary steps, defined as $D_{\mathrm{H}-\mathrm{H}}$

\begin{tabular}{lccc}
\hline$D_{\mathrm{H}-\mathrm{H}} / \AA$ & $\mathrm{H}_{2, \text { dis }}{ }^{*}$ & $\mathrm{OH}^{*}+\mathrm{H}_{2}{ }^{*}$ & $\mathrm{O}^{*}+\mathrm{H}_{2}{ }^{*}$ \\
\hline $\mathrm{Cu}(211)$ & 1.39 & 0.87 & 0.90 \\
$\mathrm{Au}(211)$ & 1.35 & 0.91 & 0.85 \\
$\mathrm{Ag}(211)$ & 1.55 & 0.95 & 0.84 \\
$\mathrm{Ni}(211)$ & 1.28 & 1.05 & 1.04 \\
$\mathrm{Pt}(211)$ & 1.30 & 1.11 & 1.04 \\
$\mathrm{Cu}(111)$ & 1.38 & 0.97 & 0.91 \\
$\mathrm{Au}(111)$ & 1.33 & 0.85 & 0.83 \\
$\mathrm{Ag}(111)$ & 1.27 & 0.91 & 0.84 \\
$\mathrm{Ni}(111)$ & 1.13 & 1.01 & 0.99 \\
$\operatorname{Pt}(111)$ & 1.15 & 1.01 & 0.95
\end{tabular}

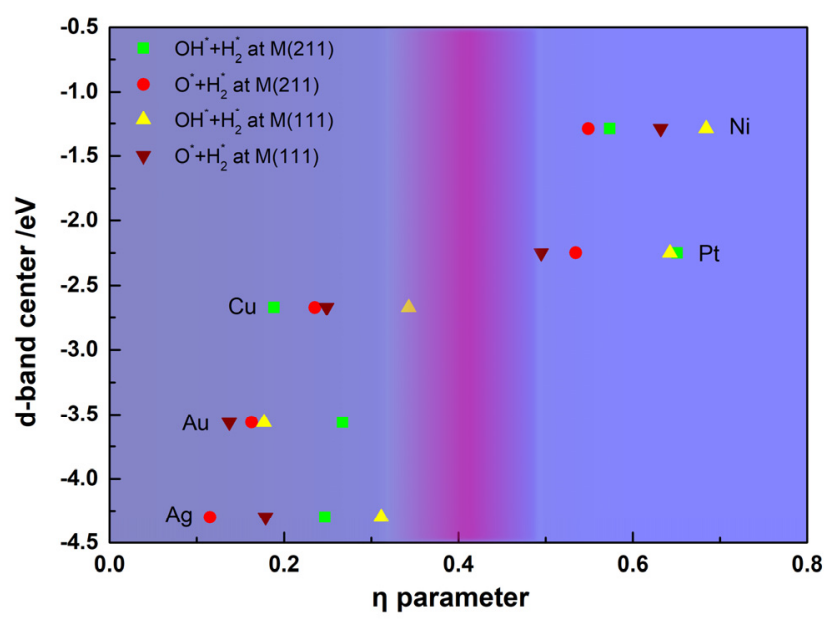

Fig. 5. d-band centers of transitional metals as a function of the parameter $\eta$ for the TSs of the hydrogenation reactions: the green squares and yellow up-triangles represent the reaction of $\mathrm{OH}^{*}+\mathrm{H}_{2}{ }^{*}$ on (211) and (111) surfaces, respectively, whereas the red circles and brown down-triangles represent the reaction of $\mathrm{O}^{*}+\mathrm{H}_{2}{ }^{*}$ on (211) and (111) surfaces, respectively.

non-HP mechanism are similar to the $\mathrm{H}-\mathrm{H}$ distance in the gas phase, which is observed on inactive metal surfaces with highly negative values of $d$-band centers. On the right hand side of Fig. 5 , the data points of $\eta$ for the active metals are characterized by the d-band center located in the region beyond $\eta=0.41$, which suggests that the $\mathrm{H}-\mathrm{H}$ bond length is close to that of $\mathrm{H}-\mathrm{H}$ dissociation distance and, thus, the HP mechanism can be distinguished from the non-HP mechanism.

Having presented the results above, it is worth discussing the results of Fig. 1 further. The boundary marked by $E_{\mathrm{a}}=0.4$ $\mathrm{eV}$ is found to realize the goal of dividing all the data points into two parts, as illustrated in Fig. 1(a, b). The region below $0.4 \mathrm{eV}$ is the area in which $\mathrm{H}_{2}$ can readily dissociate, namely, the catalytically active region for $\mathrm{H}_{2}$ dissociation. The region above 0.4 $\mathrm{eV}$ is the area in which $\mathrm{H}_{2}$ dissociation is not active. Interestingly, the energy of $0.4 \mathrm{eV}$ is the entropy of $\mathrm{H}_{2}$ in the gas phase at room temperature. In summary, $\mathrm{H}_{2}$ dissociation occurs most likely in the region below $0.4 \mathrm{eV}$, whereas, in the region above $0.4 \mathrm{eV}$, the mechanism of hydrogenation by $\mathrm{H}_{2}$ is preferred.

\section{Conclusions}

The non-HP mechanism of $\mathrm{OH}^{*}$ and $\mathrm{O}^{*}$ hydrogenation reac- 
tions over a series of metals has been systematically investigated by DFT calculations and comprehensively compared with the classic HP hydrogenation mechanism. Some insights have been obtained. The $\mathrm{H}_{2}$ dissociation activity over a catalyst decides whether the HP mechanism or the non-HP mechanism is preferred. It is found that the energy barriers of $\mathrm{OH}^{*} / \mathrm{O}^{*}$ hydrogenation by $\mathrm{H}_{2}$ are generally lower than those of direct hydrogenation of $\mathrm{OH}^{*} / \mathrm{O}^{*}$ by $\mathrm{H}^{*}$. On active catalysts such as $\mathrm{Ni}$ and $\mathrm{Pt}$, $\mathrm{H}_{2}$ molecules prefer to dissociate, with strong adsorption energies of $\mathrm{H}^{*}$, which leads to the classic HP mechanism being favored. On inactive surfaces, e.g., $\mathrm{Au}$ and $\mathrm{Ag}$ catalysts, the $\mathrm{H}^{*}$ adsorption is weak and, therefore, the existence of $\mathrm{H}_{2}$ molecules is thermodynamically preferred, which results in the non-HP mechanism being favored. Based on these interesting results, future research can be extended to surface alloys [58] to verify the universality of the conclusions. The parameter $\eta$ was introduced to evaluate the hydrogenation mechanisms. When the $\eta$ value is higher than 0.41 , it signifies that the $\mathrm{H}-\mathrm{H}$ structure in the TS of the hydrogenation reaction is similar to the $\mathrm{H}_{2}{ }^{*}$ dissociation structure; the HP mechanism will then be favored. In contrast, the non-HP mechanism is favored if $\eta<$ 0.41 and $E_{\mathrm{a}}$ of $\mathrm{H}_{2}{ }^{*}$ dissociation is relatively high.

\section{References}

[1] F. Fischer, H. Tropsch, Ber. Deutsch. Chem. Ges., 1926, 59, 830-831.

[2] Z. P. Liu, P. Hu, J. Am. Chem. Soc., 2002, 124, 11568-11569.

[3] J. Cheng, X. Q. Gong, P. Hu, C. M. Lok, P. Ellis, S. French, J. Catal,, 2008, 254, 285-295.

[4] S. G. Wang, D. B. Cao, Y. W. Li, J. Wang, H. Jiao, Surf. Sci., 2009, 603, 2600-2606.

[5] J. Wang, H. Wang, P. Hu, Sci. China Chem., 2018, 61, 336-343.

[6] Holleman, A. E. Wiberg, Lehrbuch der anorganischen Chemie, Academic Press, Berlin/New York, 2001.

[7] K. C. Waugh, Catal. Lett., 2012, 142, 1153-1166.

[8] Y. Yang, C. A. Mims, D. H. Mei, C. H. F. Peden, C. T. Campbell, J. Catal., 2013, 298, 10-17.

[9] X. Nie, M. R. Esopi, M. J. Janik, A. Asthagiri, Angew. Chem. Int. Ed.,
2013, 52, 2459-2462.

[10] X. Sun, X. Cao, P. Hu, Sci. China Chem., 2015, 58, 553-564.

[11] Y. Chen, J. Cheng, P. Hu, H. Wang, Surf. Sci., 2008, 602, 2828-2834.

[12] G. H. Graaf, E. J. Stamhuis, A. A. C. M. Beenackers, Chem. Eng. Sci., 1998, 43, 3185-3195.

[13] J. Horiuti, M. Polanyi, Nature, 1933, 132, 819.

[14] I. Horiuti, M. Polanyi, Trans. Faraday Soc., 1934, 30, 1164-1172.

[15] B. Yang, X. Q. Gong, H. F. Wang, X. M. Cao, J. J. Rooney, P. Hu, J. Am. Chem. Soc., 2013, 135, 15244-15250.

[16] G. Vilé, D. Baudouin, I. N. Remediakis, C. Copéret, N. López, J. Pérez-Ramírez, ChemCatChem, 2013, 5, 3750-3759.

[17] M. Araki, V. Ponec, J. Catal., 1976, 44, 439-448.

[18] F. Studt, I. Sharafutdinov, F. A. Pedersen, C. F. Elkjær, J. S. Hummelshøj, S. Dahl, I. Chorkendorff, J. K. Nørskov, Nat. Chem., 2014, 6, 320-324.

[19] B. Yang, R. Burch, C. Hardacre, G. Headdock, P. Hu, ACS Catal., 2012, 2, 1027-1032.

[20] H. S. Bengaard, J. K. Nørskov, J. Sehested, B. S. Clausen, L. P. Nielsen, A. M. Molenbroek, J. R. Rostrup-Nielsen, J. Catal., 2002, 209, 365-384.

[21] N. Mota, R. Guil-Lopez, B. G. Pawelec, J. L. G. Fierro, R. M. Navarro, RSC Adv., 2018, 8, 20619-20629.

[22] M. Behrens, F. Studt, I. Kasatkin, S. Kuhl, M. Havecker, F. Abild-Pedersen, S. Zander, F. Girgsdies, P. Kurr, B. L. Kniep, M. Tovar, R. W. Fischer, J. K. Norskov, R. Schlogl, Science, 2012, 336, 893-897.

[23] J. Sehested, Catal. Today, 2006, 111, 103-110.

[24] A. Ochoa, A. Arregi, M. Amutio, A. G. Gayubo, M. Olazar, J. Bilbao, P. Castaño, Appl. Catal. B, 2018, 233, 289-300.

[25] P. Tahay, Y. Khani, M. Jabari, F. Bahadoran, N. Safari, Appl. Catal. A, 2018, 554, 44-53.

[26] D. W. Goodman, R. D. Kelley, T. E. Madey, J. T. Yates Jr., J. Catal., 1980, 63, 226-234.

[27] J. Sehested, S. Dahl, J. Jacobsen, J. R. Rostrup-Nielsen, J. Phys. Chem. $B, \mathbf{2 0 0 5}, 109,2432-2438$.

[28] Q. Fu, H. Saltsburg, M. Flytzani-Stephanopoulos, Science, 2003, 301, 935-938.

[29] J. Knudsen, A. U. Nilekar, R. T. Vang, J. Schnadt, E. L. Kunkes, J. A. Dumesic, M. Mavrikakis, F. Besenbacher, J. Am. Chem. Soc., 2007,

\section{Graphical Abstract}

Chin. J. Catal., 2020, 41: 294-301 doi: S1872-2067(19)63434-0

\section{General trends in Horiuti-Polanyi mechanism vs non-Horiuti-Polanyi mechanism for water formation on transition metal surfaces}

Xitong Sun, Jianfu Chen *, P. Hu *

East China University of Science and Technology, China;

Queen's University Belfast, $U K$

A thorough investigation of the Horiuti-Polanyi (HP) mechanism and the non-HP mechanism for hydroxyl/oxygen hydrogenation catalyzed by transition metals has been carried out through first-principles calculations, and the descriptor $\eta$ was defined to understand the different mechanisms.

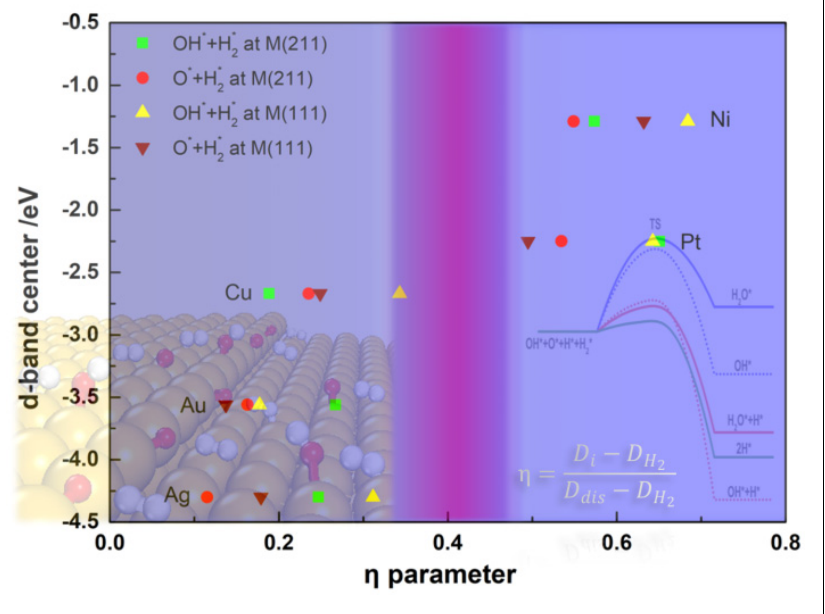


$129,6485-6490$.

[30] Y. Mao, J. Chen, H. Wang, P. Hu, Chin. J. Catal., 2015, 36, 1596-1605.

[31] M. Yang, H. Yuan, H. Wang, P. Hu, Sci. China Chem., 2018, 61, 457-467.

[32] C. Huang, Z. Q. Wang, X. Q. Gong, Chin. J. Catal., 2018, 39, $1520-1526$.

[33] G. Kresse, J. Furthmüller, Phys. Rev. B, 1996, 54, 11169-11186.

[34] G. Kresse, J. Hafner, Phys. Rev. B, 1993, 47, 558-561.

[35] G. Kresse, J. Hafner, Phys. Rev. B, 1994, 49, 14251-14269.

[36] J. P. Perdew, K. Burke, M. Ernzerhof, Phys. Rev. Lett., 1996, 77, 3865-3868.

[37] J. Jin, N. Sun, W. Hu, H. Yuan, H. Wang, P. Hu, ACS Catal., 2018, 8, 5415-5424.

[38] P. E. Blöchl, Phys. Rev. B, 1994, 50, 17953-17979.

[39] G. Kresse, D. Joubert, Phys. Rev. B, 1999, 59, 1758-1775.

[40] A. Alavi, P. Hu, T. Deutsch, Silvestrellij, P. L. Uuml, R. Hutter, Phys. Rev. Lett., 1998, 80, 3650-3653.

[41] A. Michaelides, Z. P. Liu, C. J. Zhang, A. Alavi, D. A. King, P. Hu, J. Am. Chem. Soc., 2003, 125, 3704-3705.

[42] Z. P. Liu, P. Hu, J. Am. Chem. Soc., 2003, 125, 1958-1967.

[43] R. C. Catapan, A. A. M. Oliveira, Y. Chen, D. G. Vlachos, J. Phys. Chem.
C, 2012, 116, 20281-20291.

[44] H. F. Wang, Z. P. Liu, J. Phys. Chem. C, 2009, 113, 17502-17508.

[45] D. G. Vlachos, L. D. Schmidt, R. Aris, Z. Phys. D, 1993, 26(Suppl.), S156-S158.

[46] Y. A. Zhu, D. Chen, X. G. Zhou, W. K. Yuan, Catal. Today, 2009, 148, 260-267.

[47] N. B. Arboleda Jr., H. Kasai, W. A. Dino, H. Nakanishi, Jpn. J. Appl. Phys. Part 1, 2007, 46, 4233-4237.

[48] L. Zhang, X. M. Cao, P. Hu, Appl. Surf. Sci., 2017, 392, 456-471.

[49] A. A. Phatak, W. N. Delgass, F. H. Ribeiro, W. F. Schneider, J. Phys. Chem. C, 2009, 113, 7269-7276.

[50] G. C. Wang, S. X. Tao, X. H. Bu, J. Catal., 2006, 244, 10-16.

[51] B. Xing, X. Y. Pang, G. C. Wang, J. Catal., 2011, 282, 74-82.

[52] B. Xing, G. C. Wang, Phys. Chem. Chem. Phys., 2014, 16, 2621-2629.

[53] L. L. Yin, X. Q. Gong, Sci. China Chem., 2015, 58, 601-606.

[54] N. Lopez, T. V. W. Janssens, B. S. Clausen, Y. Xu, M. Mavrikakis, T. Bligaard, J. K. Nørskov, J. Catal., 2004, 223, 232-235.

[55] J. Kim, E. Samano, B. E. Koel, J. Phys. Chem. B, 2006, 110, 17512-17517.

[56] B. Hammer, Top. Catal., 2006, 37, 3-16.

[57] B. Hammer, J. K. Nørskov, Surf. Sci., 1995, 343, 211-220.

[58] H. Y. Ma, G. C. Wang, J. Phys. Chem. C, 2018, 122, 16692-16703.

\title{
过渡金属表面上水生成经典Horiuti-Polanyi机理与非Horiuti-Polanyi 机理选择的总体趋势
}

\author{
孙希䑣, 陈建富, 光, 胡培君 ${ }^{\mathrm{a}, \mathrm{b}, *}$ \\ 华东理工大学化学与分子工程学院计算化学中心, 上海200237, 中国 \\ ${ }^{\mathrm{b}}$ 女王大学化学与化学工程学院, 贝尔法斯特BT95AG, 英国
}

摘要: 在非均相催化加氢反应中, 氢气 $\left(\mathrm{H}_{2}\right)$ 一直被公认为是通过两步基元步骤参加还原反应的, 包括第一步的分子解离和 之后的反应物与原子氢键合, 即所谓的Horiuti-Polanyi (HP)机理. 直到我们研究组在Ag或Au催化丙烯醛加氢还原反应理论 研究中发现非HP机理加氢路径存在时, 新的机理才被提出, 并引起广大研究者的浓厚兴趣. 考虑到表面羟基 $(\mathrm{OH})$ 和氧 $(\mathrm{O})$ 在非均相催化体系中广泛存在, 如常见的过渡金属催化的费托合成、甲烷重整、水汽转化及氨氧化等反应, 基于第一性原 理的密度泛函理论计算方法, 我们对 $\mathrm{OH} / \mathrm{O}$ 在一系列过渡金属催化作用下还原生成水的微观机理进行了系统全面的探究.

研究发现, 不同金属对应于不同的催化氢化反应活性, 以及不同的催化反应机理. 在某些金属上 $\mathrm{H}_{2}$ 以分子形式进攻反 应物种的非HP机理有利, 而在其它金属上经典的 $\mathrm{H}_{2}$ 解离后参与氢化还原反应的HP机理更容易发生. 详细分析显示, $\mathrm{H}_{2}$ 的 解离活性决定了反应机理的种类: 在对 $\mathrm{H}_{2}$ 解离具有催化活性的金属(如 $\mathrm{Pt} 、 \mathrm{Ni}$ )表面, 不论是(211)台阶面还是(111)平面, $\mathrm{H}_{2}$ 解离几乎都是无能垒过程, 且伴随氢原子的强吸附, 反应放热明显, 导致活泼金属上HP机理更容易发生; 与之相反, 在不活 泼的催化剂表面, $\mathrm{H}_{2}$ 解离很难发生, 原子吸附也相当微弱, 相比于断键裂解, $\mathrm{H}_{2}$ 更倾向于发生分子氢化的非HP机理.

另外, 本文还定义了一个新的结构描述符 $(\eta)$ 来帮助理解两种机理发生的结构因素差异. $\eta$ 是衡量分子氢化过渡态结构 (TS)中 $\mathrm{H}-\mathrm{H}$ 键解离程度的参数, 根据其定义上下限数值分别设定为 $\mathrm{H}_{2}$ 在各催化剂表面解离过渡态的键长 $\left(D_{\mathrm{di}}\right)$ 和游离分子 态的键长 $\left(D_{\mathrm{H} 2}\right)$. 结果显示, 易发生非 $\mathrm{HP}$ 机理的催化剂表面的 TS结构对应的 $\eta$ 参数普遍低于 0.4 , 即 $\mathrm{H}-\mathrm{H}$ 原子对的确是以近分 子形式参与氢化反应; 相反发生经典 $\mathrm{HP}$ 机理的催化剂表面, $\eta$ 参数普遍在 $0.5-0.8$, 即 $\mathrm{H}-\mathrm{H}$ 即使以分子形式参与反应也是处 于近解离状态, 这预示了以解离吸附氢参与反应的优选性.

关键词: 氢化反应; Horiuti-Polanyi机理; 水的形成; 过渡金属; 密度泛函理论

收稿日期: 2019-06-09. 接受日期: 2019-06-20. 出版日期: 2020-02-05.

*通讯联系人. 电话/传真: (021)64253755; 电子信箱: p.hu@qub.ac.uk

\#通讯联系人. 电话/传真: (021)64253755; 电子信箱: jfchen@ecust.edu.cn

基金来源：国家自然科学基金(21673072, 21333003, 91845111).

本文的电子版全文由Elsevier出版社在ScienceDirect上出版(http://www.sciencedirect.com/science/journal/18722067). 